\title{
Modeling Diameter Distribution of the Tropical Rainforest in Oban Forest Reserve
}

\author{
Humphrey Igbinosa, Aigbe (Corresponding author) \\ Department of Forestry and Wildlife Management \\ Faculty of Agriculture, University of Port Harcourt \\ Choba, Port Harcourt, Nigeria
}

Tel: 234-803-401-0803Ｅ-mail: igaigbe@yahoo.com

\author{
Godwin Ejakhe, Omokhua \\ Department of Forestry and Wildlife Management \\ Faculty of Agriculture, University of Port Harcourt \\ Choba, Port Harcourt, Nigeria \\ Tel: 234-803-337-3792Ｅ-mail: profomokhua@yahoo.com
}

Received: July 23, 2014 Accepted: August 13, $2014 \quad$ Published: November 5, 2014

doi:10.5296/jee.v5i2.6559 URL: http://dx.doi.org/10.5296/jee.v5i2.6559

\begin{abstract}
Diameter distribution model was developed for tropical rainforest of Oban Forest Reserve. Multistage sampling technique was adopted for the study. The sampling procedure was made up of primary, secondary and tertiary sampling units. A total of 808 trees were measured in 14 tertiary sample plots $(40 \mathrm{~m} \times 50 \mathrm{~m})$. Tree outside bark diameter at breast height (dbh) data, were measured for tree species with $\mathrm{dbh} \geq 10 \mathrm{~cm}$ within the tertiary sampling units. Data were analysed on several probability density function (pdf), then ranked based on Kolmogorov smirnov, Anderson darling and Chi-Square. The best six distributions (Beta, Burr 4P, Gamma 3P, Johnson $\mathrm{S}_{\mathrm{B}}$, Lognormal and Weibull 3P) were further tested with Kolmogorov smirnov (D) and Chi-Square $\left(\chi^{2}\right)$ for fitting the diameter data. The results indicated that there are more trees in the lower diameter class than the upper diameter class. Weibull $3 \mathrm{P}$ and Johnson $\mathrm{S}_{\mathrm{B}}$ distribution were adjudged more flexible when tested with
\end{abstract}




\section{Macrothink}

Journal of Environment and Ecology ISSN 2157-6092 2014, Vol. 5, No. 2

Kolmogorov smirnov and Chi-Square respectively. The reason is because their calculated values (Weibull $3 \mathrm{P}=0.02397$ and Johnson $\mathrm{S}_{\mathrm{B}}=3.8161$ ) were the lowest values and less than the tabulated values $\left(\mathrm{D}=0.05\right.$ and $\left(\chi^{2}\right) \mathrm{df}_{9}=16.919$ respectively $)$ at $\mathrm{p} \geq 0.05$. This implies the data followed the specified distribution and that Weibull $3 \mathrm{P}$ and Johnson $\mathrm{S}_{\mathrm{B}}$ can appropriately provide a better fit for the diameter data in Oban Forest Reserve.

Keywords: Oban Forest Reserve, Diameter at breast height, pdf, Diameter distribution model 


\section{Introduction}

The tropical rainforest is diverse ecosystem with pronounced heterogeneity in species composition and structure. Understanding and predicting the dynamics of mixed tropical forests is difficult because, principally, of their high species diversity (Gourlet-Fleury et al, 2005). Forest managers, forest scientists and forest policy makers all rely on accumulated knowledge of the forest in order to make decisions. This knowledge may be based on their own experience or that of others, but will have originated from information collected from the forest (Phillips et al, 2002). A quantitative understanding of the forest requires quantitative data to support it, and suitable analysis to summarise the raw data to a meaningful form. The knowledge of diameter distributions is highly useful to describing and analysing the structure of forest stands. It also serves the purpose of estimating age distribution, assessing stand stability and calculating the number of trees in each diameter class with a view to planning silvicultural treatments (Carretero and Alvarez, 2013). Diameter distributions can be used to indicate whether the density of smaller trees in a stand is sufficient to replace the current population of larger trees and to help evaluate potential forest sustainability.

A wide range of probability density functions have been used in forestry to model tree diameter distributions (e.g., log-normal: Bliss and Reinker 1964; gamma: Nelson 1964; Weibull: Bailey and Dell 1973; Rennolls et al., 1985; beta: Zohrer 1972; Li et al., 2002), although the three-parameter Weibull and the four-parameter beta and SB models are possibly the most frequently used. Mohammad Alizade et al., (2009) investigated the tree diameter at breast height in uneven-aged stands and fitting a statistical distribution to them. After preliminary analysis the three exponential distributions, Gamma and Lognormal were used for fitting to data. The results of tests shows that the exponential distribution cannot determine the diameter distribution of trees and between two other distribution, Gamma distribution is more appropriate for this purpose (MohammadAlizade et al, 2009). Namiranian (1990), studied the tree distribution in diameter classes in Gorazbon district of Kheyroudkenar forest. In this study, he used three Beta, Weibull and negative binomial distributions. Results of Chi-Square and Kolmogorov-Smirnov tests showed that Weibull and Beta distributions could determine diameter distribution of trees (Namiranian, 1990).

Several authors have argued in favour of different probability density functions as the best in fitting diameter of trees. However, the current situation is that there is no clear resolution as to which model is the most suitable for tree distributional modelling (Wang and Rennolls, 2005). There is of course no theoretical reason why there should exist a best model for all situations. It might be that in one case a particular distribution will be found empirically to give the best fit, whilst in another case another model will be found to be empirically best. The only way in which it is meaningful to talk about the best distributional model is in terms of the most flexible of models in representational terms. Hence, the reason for this research is to compare a wide range of distributional models in terms of flexibility and ability on which best fit diameter of trees in Oban Forest Reserve. 


\section{Methodology}

Oban Forest Reserve lies within longitude $8^{\circ} 20^{\prime} \mathrm{E}$ and $8^{\circ} 55^{\prime} \mathrm{E}$ and latitudes $5^{\circ} 00^{\prime} \mathrm{N}$ and $6^{\circ} 00^{\prime}$ N. Presently, it cover an area of $742.55 \mathrm{~km}^{2}$ (figure 1).

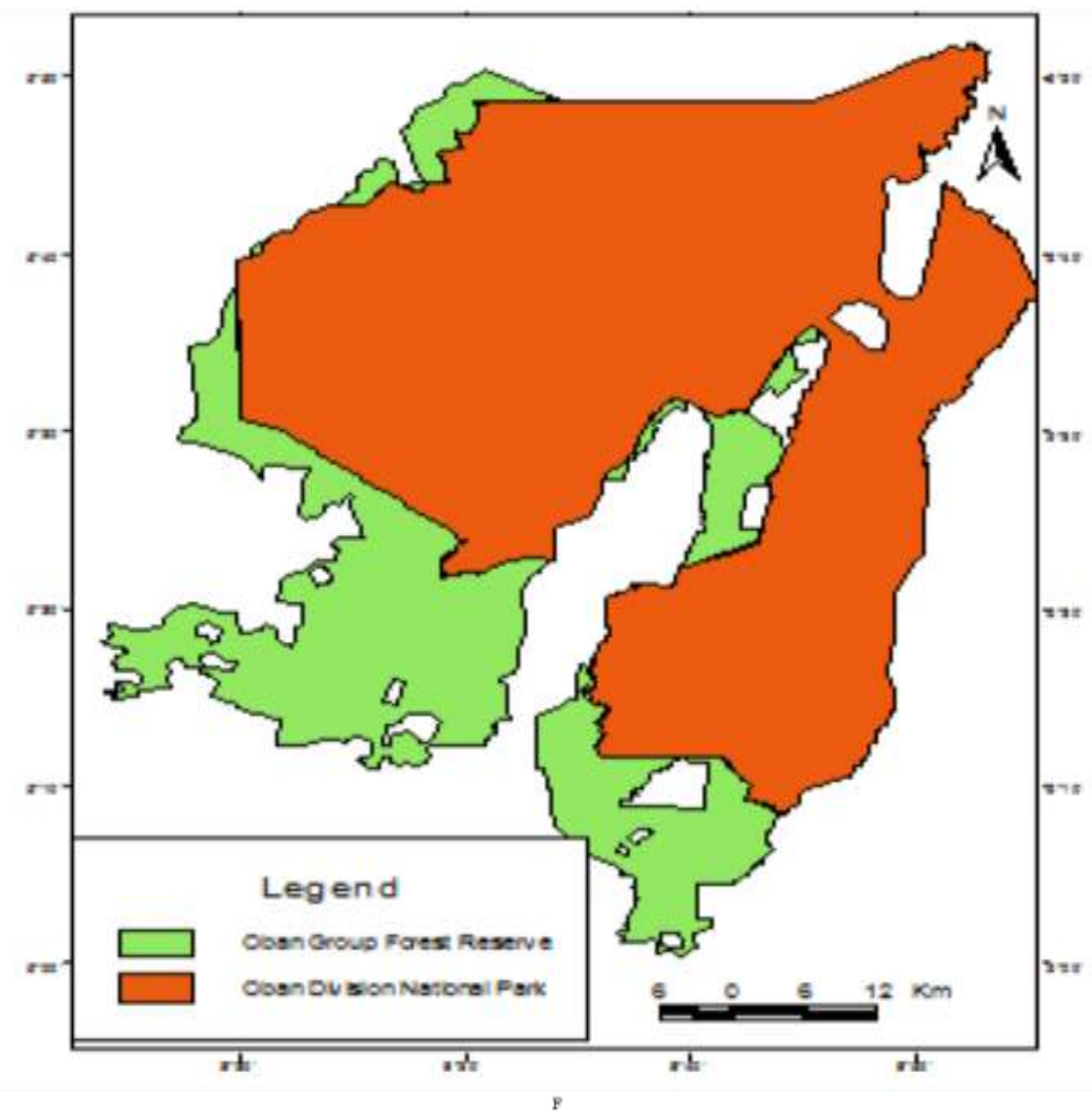

Figure 1. Map of Oban Forest Reserve

The terrain is rugged and elevation rises from the river valleys to over $1,000 \mathrm{~m}$ in mountainous areas (Jimoh et al., 2012). Most of the area is characterized by hilly terrain ranging from 100 to over $1,000 \mathrm{~m}$. The dominant rock types are ancient metamorphic rocks of the Basement Complex which covers $50 \%$ of Nigeria. The metamorphic rocks are mainly gneisses (biotite-hornblende, granite and migmatitic gneiss and to a lesser extent amphibolite (schist) (Holland et al, 1989; Schmitt, 1996). Less sandy soils are found in areas with igneous rocks and deeper soils prevail in the plains of the southern part of the park whilst on steeper slopes they are increasingly stony, shallow and erodible (Holland et al, 1989).

Temperatures are generally high (average around $27^{\circ} \mathrm{C}$ ) and vary little throughout the year with the annual range of the monthly average temperature varying only between $3^{\circ}$ and $3.5^{\circ} \mathrm{C}$. Mean monthly relative humidity varies between $78 \%$ and $91 \%$ with an average of $85 \%$. Annual rainfall is generally between $2,500 \mathrm{~mm}-3,000 \mathrm{~mm}$. At times, it can be up to $4,000 \mathrm{~mm}$. (Holland et al, 1989; Schmitt, 1996). 


\subsection{Data Collection}

Multistage sampling technique was used to establish primary $(1000 \mathrm{~m}$ x $1000 \mathrm{~m})$, secondary $(1000 \mathrm{~m} \times 50 \mathrm{~m})$ and tertiary $(40 \mathrm{~m}$ x $50 \mathrm{~m})$ sample plots. Fourteen tertiary sample plots were randomly chosen within the secondary plots and all trees above $10 \mathrm{~cm}$ diameter were considered for measurement within the tertiary plots $(0.20 \mathrm{ha})$. Tree growth data collected on trees with $\mathrm{dbh} \geq 10 \mathrm{~cm}$ in all tertiary sample plots include diameter at breast height (dbh). Data were analysed by software SPSS $17.0^{\circledR}$ and EASY FIT $5.5^{\circledR}$. Descriptive statistics such as mean, median, standard deviation and range changes were calculated and histograms were drawn.

\subsection{Data Analysis}

\section{Fitting of diameter Distribution Model}

In this study, various distribution methods were tried using Kolmogorov Smirnov, Anderson Darling and Chi- Squared goodness of fit to rank them accordingly. Relatively, six best ranked distributions were chosen to fit the diameter distribution model. In other words, the distribution used for fitting the diameter at breast height data were Johnson $\mathrm{S}_{\mathrm{B}}$, Gamma (3P), Beta, Burr (4P). Weibull (3P) and lognormal (3P).

\section{Estimating Parameters for Diameter Distribution Models}

Parameters for diameter distribution model were estimated using easy fit $5.5^{\circledR}$ software. The probability density function (pdf), cumulative distribution function, survival function, hazard function and cumulative hazard function were all equally analysed by easy fit $5.5^{\circledR}$ software. The statistical distribution models considered are represented below:

\section{Beta Distribution}

This distribution is a continuous distribution and its pdf formula is as follows:

$\mathrm{F}(\mathrm{x})=\frac{1}{B(p, q)} \frac{(x-a)^{p-1}(b-x)^{q-1}}{(b-a)^{p+q-1}}$

$\mathrm{a} \leq \mathrm{x} \leq \mathrm{b}, \mathrm{p}>0, \mathrm{q}>0$

\section{Johnson's $\mathbf{S}_{\mathbf{B}}$}

The $S_{B}$ distribution is obtained by the following four-parameter logistic transformation of a standard normal variate, $\mathrm{z}$. The $\mathrm{S}_{\mathrm{B}}$ pdf is given as:

$\mathrm{F}(\mathrm{x})=\mathrm{F}(\mathrm{z})\left(\frac{d_{x}}{d_{z}}\right)^{-1}=\frac{1}{\sqrt{2 \pi}} e^{-\frac{1}{2} z^{2}} \times \frac{\lambda}{\sigma(\xi+\lambda-x)(x-\xi)}$

Where $\mathrm{z}$ is given as: 
$\mathrm{z}=\frac{\operatorname{In}\left(\frac{x-\xi}{\xi+\lambda-x}\right)-\mu}{\sigma}$

$\mu=\gamma / \delta$ and $\sigma=1 / \delta$

\section{Weibull Distribution}

Weibull distribution was also presented as an cumulative frequency in which a is the starting point and $b$ presents the curve's concavity degree, and $\mathrm{c}$ is the curve's factor form or shape index and its mathematical process is as follows:

$$
\mathrm{F}(\mathrm{x})=1-e^{-\left(\frac{x-a}{b}\right)^{c}}
$$

$\mathrm{a} \geq a, b>0, c>0$

\section{Burr Distribution}

The four-parameter Burr XII (Burr 1942, 1968, 1973; Burr and Cislak 1968; Rodriguez 1977) distribution does not seem to have been previously evaluated for forest modelling but is adopted for this study because of the simple form of its Cumulative Distribution Function.

$$
\mathrm{F}(\mathrm{x})=1-\frac{1}{1+\left\lfloor\left(\frac{x-a}{b}\right)^{c}\right]^{k}}
$$

$\mathrm{a} \geq a, b>0, c>0 K>0$

\section{Lognormal Distribution}

This is a continuous distribution and its natural logarithm has a normal distribution.

$$
\mathrm{F}(\mathrm{x})=\frac{1}{\sqrt{2 \pi \delta x}} \exp \left[-\frac{1}{2 \delta^{2}}(\operatorname{In} x-\mu)^{2}\right]
$$

$\delta>0, x>0,0<\mu+\infty$

\section{Gamma Distribution}

This distribution is a continuous distribution and it has a good flexibility and its frequency curve in all modes has a lean towards right. 
$\mathrm{F}(\mathrm{x})=\frac{x^{\alpha-1}}{\beta T(\alpha)} \exp \left(\frac{-x}{\beta}\right)$

$0 \leq x<+\infty \quad \alpha, \beta>0$

\section{Results and Discussion}

Diameter Distribution Model

The summary of the descriptive statistics and goodness of fit of diameter distribution functions for Oban Forest Reserve are presented on Tables 1 and 2. The value of the skewness is 1.584 while that of excess kurtosis (leptokurtic curve) is 3.402 (Table 1). High positive skewness and peakedness means that considerable numbers of trees are concentrated in the lower diameter classes (Gadow, 1983). The goodness of fit of the distributions were tested with Kolmogorov smirnov, Anderson Darling and Chi-Square as shown in Table 2. Based on ranking, six distributions were selected. The six distributions were further tested with Kolmogorov smirnov and Chi-Square. The Kolmogorov smirnov test indicate that the six distributions can provide good fits for the diameter data, because their calculated D-values (Beta: 0.02609: Burr 4P: 0.02402; Gamma 3P: 0.03147; Johnson $\mathrm{S}_{\mathrm{B}}$; 0.02888: Lognormal: 0.049 and Weibull 3P: 0.02397) were less than their tabulated D-value (0.05). This implies the null hypotheses were accepted for all the distributions, meaning the data followed the specified distribution. However, Weibull 3P distribution was more flexible in fitting the diameter data when tested with Kolmogorov smirnov because it has the lowest calculated D-values. Weibull distribution was adjudged more flexible in a research carried out in Gorazbon district of Kheyroudkenar forest by Namiranian (1990) and Mataji et al., (2000). Both scientists, using Kolmogorov-Smirnov tests showed that Weibull distributions could determine diameter distribution of trees. Some researchers suggest that Wiebull distribution had greater capability to define tree's diameter distribution (Mataji et al., 1999) and also, during study on diameter data for pinus teada, defines Weibull probability distribution as a suitable model (Cao, 2004). Several authors (Okojie, 1981; Cao et al, 1982; Adegbehin, 1985; Akindele and Abayomi, 1983; Abayomi, 1983; and Akindele, 2002) have demonstrated the use of Weibull probability distribution functions for predicting diameter distribution in even aged stand. Clutter et al., (1983) described Weibull function as the most popular frequency distribution model.

The use of Chi-Square test indicate that five of the distributions can only fit the diameter data in Oban Forest Reserve because the tabulated Chi-Square $\left(\chi^{2} \mathrm{df}_{9}=16.919\right)$ at $95 \%$ probability level is greater than the calculated values of (Beta $=5.2958$; Burr $4 \mathrm{P}=4.7544$; Gamma 3P $=4.9378$; Johnson $S_{B}=3.8161$ and Weibull 3P = 4.7612). This implies the null hypotheses were accepted for the five distributions, meaning the data followed the specified distribution. However, the Johnson $\mathrm{S}_{\mathrm{B}}$ distribution for Chi-Square test was more flexible in fitting the diameter data because it has the lowest calculated value. This is in agreement with 


\section{Macrothink}

Wang and Rennoll (2005) and Zhang et al., (2003) that stated Johnson's $S_{\mathrm{B}}$ models are possibly the most frequently used. Hafley and Schreuder (1977) compared the beta, Johnson's $S_{\mathrm{B}}$, Weibull, log-normal, gamma, and normal distributions in terms of their coverage. They concluded that Johnson's $S_{\mathrm{B}}$ gave the best performance in terms of the quality of fitting a variety of sample distributions (tree diameter and height data). Subsequently, Johnson's $S_{\mathrm{B}}$ and its bivariate version have been much used and compared with other common distributional models (Hafley and Buford 1985; Knoebel and Burkhart 1991; Zhou and McTague 1996; Kamziah et al. 1999; Tewari and Gadow 1997, 1999; Scolforo et al. 2003).

Table 1. Summary of Descriptive Statistics for dbh Class in Oban Forest Reserve

\begin{tabular}{llcc}
\hline Statistic & Value & Percentile & Value/cm \\
\hline Sample Size & 808 & Min & 10.00 \\
Range & 1.24 & $5 \%$ & 12.15 \\
Mean & 0.3372 & $10 \%$ & 14.19 \\
Variance & 0.03929 & $25 \%$ & 19.63 \\
Std. Deviation & 0.19823 & $50 \%$ & 28.85 \\
Coef. of Variation & 0.58786 & $75 \%$ & 41.60 \\
Std. Error & 0.00697 & $90 \%$ & 60.40 \\
Skewness & 1.584 & $95 \%$ & 78.92 \\
Excess Kurtosis & 3.4017 & Max & 138.00 \\
\hline
\end{tabular}

Table 2. Summary of Goodness of Fit of Distribution Functions for Oban Forest Reserve

Reserve

\begin{tabular}{llcccccc}
\hline s/n & Distribution & \multicolumn{2}{c}{$\begin{array}{c}\text { Kolmogorov } \\
\text { Smirnov }\end{array}$} & \multicolumn{2}{c}{$\begin{array}{c}\text { Anderson } \\
\text { Darling }\end{array}$} & \multicolumn{2}{c}{ Chi-Squared } \\
\hline & & Statistic & Rank & Statistic & Rank & Statistic & Rank \\
1 & Beta & 0.02609 & 3 & 0.53809 & 3 & 5.2958 & 5 \\
2 & Burr (4P) & 0.02402 & 2 & 0.46898 & 1 & 4.7544 & 2 \\
3 & Gamma (3P) & 0.03147 & 5 & 0.54477 & 4 & 4.9378 & 4 \\
4 & Johnson SB & 0.02888 & 4 & 0.56359 & 5 & 3.8161 & 1 \\
5 & Lognormal & 0.049 & 6 & 1.7688 & 6 & 21.757 & 6 \\
6 & Weibull (3P) & 0.02397 & 1 & 0.49675 & 2 & 4.7612 & 3 \\
\hline
\end{tabular}

Table 3 shows the parameter values of the six distribution functions while Figure 2 shows that the distribution pattern of the $\mathrm{dbh}(\mathrm{m})$ of trees in Oban forest reserve is positively skewed. 


\section{Macrothink}

This pattern shows that there are more trees in lower dbh class that is sufficient enough to replace trees in the upper dbh class in the future (i.e. when the big trees are harvested or when they die). This is consistent with previous reports for two other tropical rainforests (Boubli et al., 2004; Bobo et al., 2006). Adekunle (2002) also reported positive skewness distribution pattern for Ala and Omo Forest Reserves in Nigeria. The implication of this is that the forests are still undergoing regeneration and recruitment, which are vital indicators of forest health and vigour (Jimoh et al. (2011).

The graphs of observed and estimated probability functions of dbh class of the distribution functions show that there is no significant difference $(p>0.05)$ between the empirical and theoretical cumulative functions (Figures $3 \mathrm{a}-\mathrm{f}$ ). This means there is no difference between the observed and predicted diameter frequencies.

Table 3. Distribution Parameter Estimates for Oban Forest Reserve

\begin{tabular}{clccc}
\hline $\mathrm{s} / \mathrm{n}$ & Distribution & Parameters & & \\
\hline 1 & Beta & $\alpha_{1}=1.2866$ & $\alpha_{2}=19.771$ & \\
& & $\mathrm{a}=0.09903$ & $\mathrm{~b}=3.9967$ & \\
2 & Burr (4P) & $\mathrm{k}=69.743$ & $\alpha=1.2182$ & \\
& & $\beta=8.1826$ & $\gamma=0.09935$ & \\
3 & Gamma (3P) & $\alpha=1.3808$ & $\beta=0.17301$ & $\gamma=0.09832$ \\
& & $\gamma=2.6722$ & $\delta=1.2292$ & \\
4 & Johnson SB & $\lambda=2.2355$ & $\xi=0.0569$ & \\
5 & Lognormal & $\sigma=0.54327$ & $\mu=-1.2375$ & \\
6 & Weibull (3P) & $\alpha=1.2062$ & $\beta=0.25299$ & $\gamma=0.09942$ \\
\hline
\end{tabular}




\section{Histogram}

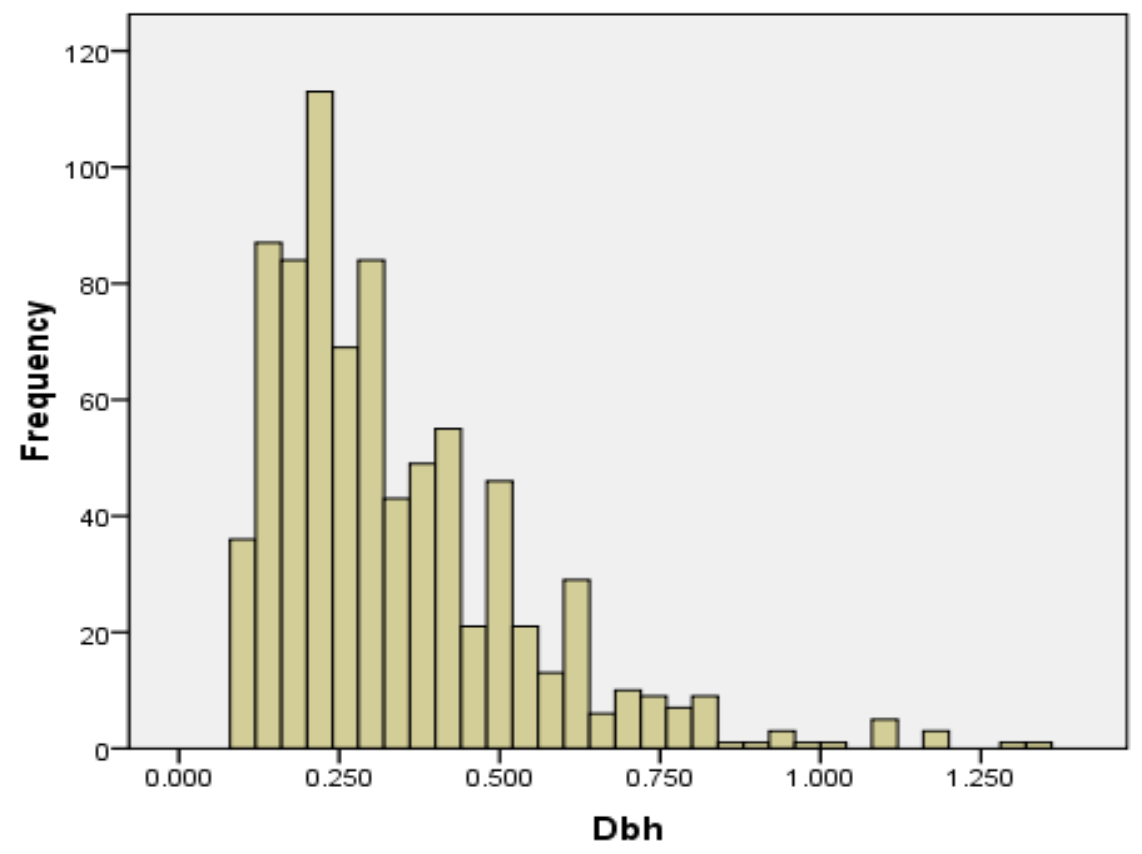

$\begin{aligned} \text { Mean } & =0.34 \\ \text { Std. Dev. } & =0.198\end{aligned}$

$\mathrm{N}=808$

Figure 2. Dbh Distribution Pattern of Oban Forest Reserve

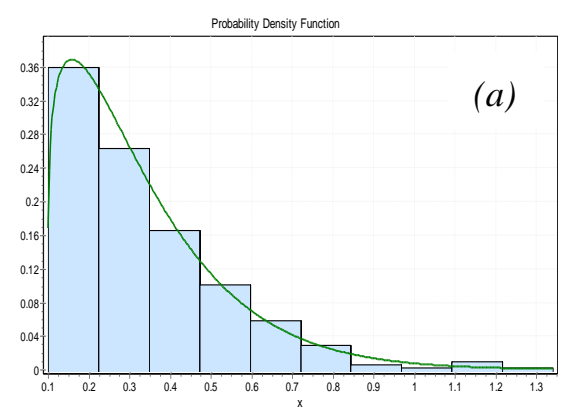

QHistogram - Weibul (3P)

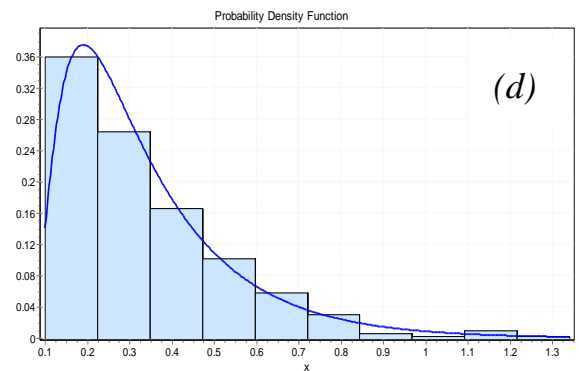

Q Histogram - Johnson SB

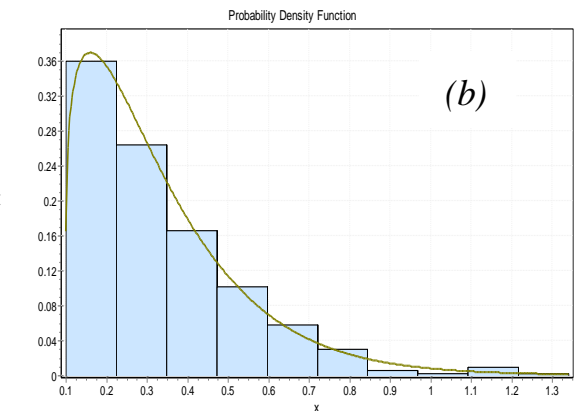

QHistogram - Bur (4P)

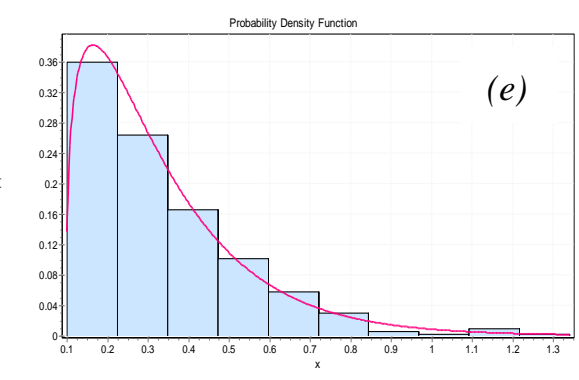

[Histogram -Gamma | |3P]

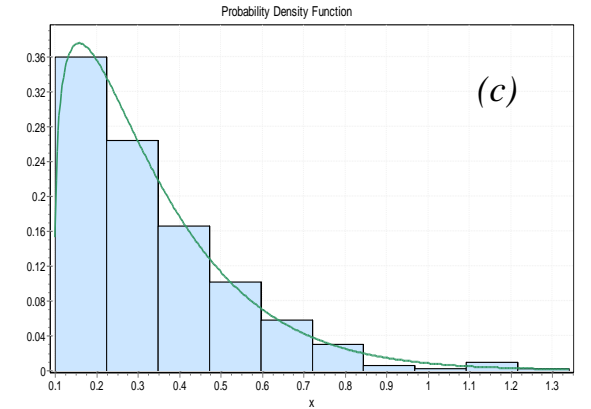

पilistogram - Beta

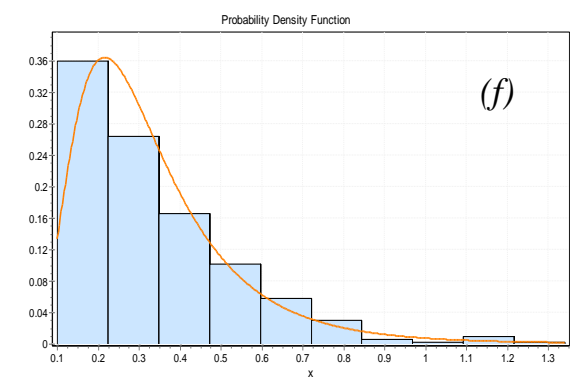

QHistogram-Lognormal

Figure 3. (a) Weibull (3P); (b) Burr (4P); (c) Beta; (d) SB; (e) Gamma (3P) and (f) Lognormal graphs of observed and estimated probability function of dbh class for Oban Forest Reserve 
Table 4 shows the distribution's account results of 808 trees in the observed diameter class and their evaluation with Weibull probability distribution at $13 \mathrm{~cm}$ dbh class interval. The result of the predicted dbh frequencies (Table 4) shows that there are more trees in the lower dbh class than in the upper dbh class. The $t$ - test carried out for the observed and predicted $\mathrm{dbh}$ frequencies indicates that the $\mathrm{t}$ - statistic of 0.1272 is less than the critical level of 2.2623 , meaning, there is no significant difference $(\mathrm{p}>0.05)$ between the observed and predicted dbh frequencies and the correlation between the observed and predicted dbh frequencies was $\mathrm{R}=$ 0.996. Similar results were reported by Fallahchai and Hashemi (2011), in North of Iran forest and Ige et al., (2013), in Onigambari Forest Reserve, Nigeria.

Table 4. Dbh frequency distribution in the observed diameter class and evaluation with Weibull distribution in Oban Forest Reserve

\begin{tabular}{crr}
\hline Dbh class & $\begin{array}{c}\text { Observed } \\
\text { frequencies }\end{array}$ & $\begin{array}{c}\text { Predicted } \\
\text { frequencies }\end{array}$ \\
\hline $10-22$ & 291 & 299 \\
$23-34$ & 210 & 226 \\
$35-47$ & 129 & 141 \\
$48-60$ & 81 & 71 \\
$61-73$ & 48 & 32 \\
$74-86$ & 23 & 19 \\
$87-99$ & 7 & 15 \\
$100-112$ & 3 & 7 \\
$113-125$ & 13 & 4 \\
$126-138$ & 3 & 3 \\
\hline
\end{tabular}

\section{Conclusion}

The diameter distribution model was successfully estimated using the graph of probability density function that confirmed the expected frequencies in each dbh class. Using appropriate probability theories to predict trees distribution in tropical rainforest is important in estimation of productivity in different dbh class. In this study, probability distributions were applied to estimate the diameter distribution, and statistical methods were used to provide diameter distribution models. Weibull (3P) and Johnson $\mathrm{S}_{\mathrm{B}}$ distributions were more flexible in fitting the diameter data in Oban Forest Reserve when tested with Kolmogorov smirnov and Chi Square respectively. It shows that there is no clear resolution as to which model is the most suitable for tree distributional modelling. In one case a particular distribution will be found empirical to give the best fit, whilst in another case another model will be found to be empirically best. The only way in which it is meaningful to talk about the best distributional model is in terms of the most flexible of models in representational terms.

Diameter distribution model reveal structure of stand or forest and its development is recommended for application in scheduling silvicultural treatment in Oban Forest Reserves. Further and more comprehensive study in this area is recommended. More studies are needed to achieve more applied results. 


\section{Acknowledgement}

The research is partly financed by Tertiary Education Trust Fund, Nigeria. I wish to thank Professors S. O. Akindele and J. C. Onyekwelu for their contribution and constructive critisicm.

\section{Reference}

Abayomi, J. A. (1983). Volume tables for Nauclea diderrichii in Omo forest reserve, Nigeria. Nigerian J. Forest, 13(1-2), 46-52.

Adegbehin J. O. (1985). Growth prediction in some plantations of exotic species in the savana zone of Nigeria. PhD thesis, University of Ibadan, Ibadan, Nigeria. 328p.

Adekunle, V. A. J. (2002). Inventory techniques and models for yield and tree species assessment in Ala and Omo Forest Reserve, southwestern Nigeria. PhD Thesis, Department of Forestry and Wood Technology, Federal University of Technology, Akure. 170p.

Akindele, S. O., \& Abayomi, J. O. (1983). Stem - diameter distribution in permanent sample plot of Nauclea diderrichii in Southwest Nigeria. In (Vanclay J.K, Skovsgaard, J.P and Gertner, L.Z. Editors): Growth and yield estimation from successive inventories. Proceedings of IUFRO Conference. 14 - 17 June 1993, Copenhangen 281 pp.

Bailey, R. L., \& Dell, T. R. (1973). Quantifying diameter distributions with the Weibull function. Forest. Science, 19, 97-104.

Bliss, C. I., \& Reinker, K. A. (1964). A lognormal approach to diameter distributions in even-aged stands. Forest Science, 10, 350-360.

Bobo, K. S., Waltert, M., Sainge, M., Njokagbor, J., Fermon, H., \& Mühlenberg, M. (2006). From forest to farmland: Species richness patterns of trees and understorey plants along a gradient of forest conversion in Southwestern Cameroon. Biodiversity and Conservation, 15, 4097-4117.

Boubli, J. P., Eriksson, J., Wich, S., Hohmann, G., \& Fruth, B. (2004). Mesoscale transect sampling of trees in the Lomako-Yekokora interfluvium, Democratic Republic of the Congo. Biodiversity and Conservation, 13, 2399-2417.

Burr, I. W. (1942). Frequency functions. Ann. Math. Stat., 13, 215-232.

Burr, I. W. (1968). On a general system of distributions. III. The sample range. J. Am. Stat. Assoc., 63, 636-643.

Burr, I. W. (1973). Parameters for a general system of distributions to match a grid of $\alpha 3$ and a4. Commun. Stat., 2(1), 1-21.

Burr, I. W., \& Cislak, P. J. (1968). On a general system of distributions. I. Its curve-shaped characteristics. II. The sample median. J. Am. Stat. Assoc., 63, 627-635.

Cao, Q. V. (2004). Predicting parameters of a weibull function for modeling diameter distribution. Forest Science, 50(5), 682-685. 
Cao, Q. V., Burkhart, H. E., \& Lemin, R. C. (1982). Diameter distribution and yields of Thinned loblolly pine plantations. School of Forestry and Wildlife Resources, VPI and SU publication No. FSW - $1-82$.

Carretero, A. C., \& Alvarez, E. T. (2013). Modelling diameter distributions of Quercus suber L. stands in "Los Alcornocales" Natural Park (Cádiz-Málaga, Spain) by using the two parameter Weibull functions. Instituto Nacional de Investigación y Tecnología Agraria y Alimentaria (INIA). Forest Systems, 22(1), 15-24.

Clutter, J. L., Fortson, J. C., Pienaar, L. V., Brister, G. H., \& Bailey, R. L. (1983). Timber Management: A Quantitative Approach. John Wiley and Sons, New York. 333pp.

Fallahchai, M. M., \& Hashemi, S. A. (2011). The application of some probability distributions in order to fit the trees.. Appl. Environ. Biol. Sci., 1(10), 397-400.

Gadow, K. V. (1983). Fitting distributions in Pinus patula stands. South African Forestry Journal, 20-29.

Gourlet-Fleury, S., Blanc, L., Picard, N., Sist P., Dick J., Nasi R., Swaine, M. D., \& Forni., E. (2005). Grouping species for predicting mixed tropical forest dynamics: Looking for a strategy. Ann. Forest Science, 62, 785-796.

Hafley, W. L., \& Buford, M. A. (1985). A bivariate model for growth and yield prediction. For. Sci., 31, 237-247.

Hafley, W. L., \& Schreuder, H. T. (1977). Statistical distributions for fitting diameter and height data in even-aged stands. Can. J. For. Res., 7, 481-487.

Holland, M. D., Allen, R. K. G., Barton, D., \& Murphy, S. T. (1989). Cross River National Park (Oban Division); Land Evaluation and Agricultural Recommendations. World Wide Fund for Nature, Godalming, United Kingdom. 140 pp.

Ige P. O., Akinyemi, G. O., \& Abi, E. A. (2013). Diameter distribution models for tropical natural forest trees in Onigambari Forest Reserve. Journal of Natural Science Research, $3(12), 14-22$.

Jimoh S. O., Adesoye P. O., Adeyemi A. A., \& Ikyaagba, E. T. (2012). Forest Structure Analysis in the Oban Division of Cross River National Park, Nigeria. Journal of Agricultural Science and Technology B 2 510-518.

Kamziah, A. K., Ahmad, M. I., \& Lapongan J. (1999). Nonlinear regression approach to estimating Johnson SB parameters for diameter data. Can. J. For. Res., 29, 310-314.

Knoebel, B. R., \& Burkhart, H. E. (1991). A bivariate distribution approach to modelling forest diameter distributions at two points of time. Biometrics, 47, 241-253.

Li, F., Zhang, L., \& Davis, C. J. (2002). Modeling the joint distribution of tree diameters and heights by bivariate generalized beta distribution. Forest Science, 48(1), 47-58.

Mataji, A, Hojati, M., \& Namiranian, M. (2000). The study of quantity distribution in 
diameter levels in natural forests by using probability distribution. Iran's natural resources magazine, 53(2), 165-171.

MohammadAlizade, K. H., Zobeiri, M., Namiranian, M., Hourfar, A., Mohajer, M. (2010). Fitness of distribution of diameter at breast height by using some statistic distribution models. Iranian journal of forest and poplar research, 17(1), 116 - 124.

Namiranian M. (1990). The application of probability theories in determining trees distribution in different diameter levels. Iranian Journal natural resource, 44, 93-108.

Nelson, T. C. (1964): Diameter distribution and growth of loblolly pine. Forest Science, 10, $105-115$.

Okojie, J. A. (1981). Models of stand development in some plantations of indigenous meliaceae in moist tropical rainforest region of Nigeria. $\mathrm{PhD}$ thesis, U.I. Ibadan.

Phillips, P. D., Yasman, I., Brash, T. E., \& van Gardingen, P. R. (2002). Grouping tree spp. for analysis of forest data in Kalimantan (Indonesian Borneo). Forest Ecology and Mgt. 157, 205-216.

Rennolls, K., Geary, D. N., \& Rollinson, T. J. D. (1985). Characterizing diameter distribution by the use of the Weibull distribution. Forestry, 58, 57-66.

Rodriguez, R. N. (1977). A guide to the Burr type XII distributions. Biometrika, 64(1), 129-134.

Schmitt, K. (1996). Zoological survey of the Oban division of Cross River National Park Oban Hill programme, Calabar. Pp 21.

Scolforo et al. (2003). SB distribution's accuracy to represent the diameter distribution of Pinus taeda, through five fitting methods. For. Ecol. Manage., 175, 489-496.

Tewari, V. P., \& Gadow, K. V. (1997). Fitting a bivariate distribution to diameter-height data of forest trees. Indian For, 123, 815-820.

Wang, M., \& Rennolls, K. (2005). Tree diameter distribution modelling: Introducing the logit - logistic distribution. Can. J. For. Res., 35, 1305-1313.

Zhou, B., and\& McTague, J. P. (1996). Comparison and evaluation of five methods of estimation of the Johnson system parameters. Can. J. For. Res., 26, 928-935.

Zohrer, F. (1972). The beta distribution for best fit of stem diameter distribution. $3^{\text {rd }}$ Conf. Advisory Group For. Stat. Proc. IUFRO, Institut National Recherche Agronomique, Paris. 